\title{
Performance and methane emissions in dairy cows fed oregano and green tea extracts as feed additives
}

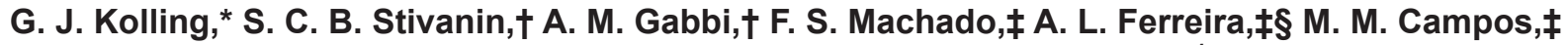 \\ T. R. Tomich, $\ddagger$ C. S. Cunha,\# S. W. Dill,II L. G. R. Pereira, $\ddagger$ and V. Fischer ${ }^{1}$ \\ *Department of Veterinary Medicine, Escola de Medicina Veterinária University Center FACVEST and IMED, Passo Fundo, 99070-220, \\ Rio Grande do Sul, Brazil \\ †Department of Animal Science, Universidade Federal do Rio Grande do Sul, Porto Alegre, 91540-000, Rio Grande do Sul, Brazil \\ †Brazilian Agricultural Research Corporation, Embrapa Dairy Cattle, Juiz de Fora, 36038-330, Minas Gerais, Brazil \\ §Universidade Federal de São João del Rei, São João del Rei, 36307-352, Minas Gerais, Brazil \\ \#Doctor in Animal Science from Universidade Federal de Viçosa, Viçosa, 36570-000, Minas Gerais, Brazil \\ IIIntegrated Residency Program in Veterinary Medicine, Universidade Federal do Pampa, Uruguaiana, 97504210, Rio Grande do Sul, Brazil
}

\begin{abstract}
Plant extracts have been proposed as substitutes for chemical feed additives due to their potential as rumen fermentation modifiers and because of their antimicrobial and antioxidant activities, possibly reducing methane emissions. This study aimed to evaluate the use of oregano (OR), green tea extracts (GT), and their association as feed additives on the performance and methane emissions from dairy between 28 and $87 \mathrm{~d}$ of lactation. Thirty-two lactating dairy cows, blocked into 2 genetic groups: 16 Holstein cows and 16 crossbred Holstein-Gir, with $522.6 \pm 58.3 \mathrm{~kg}$ of body weight, 57.2 $\pm 20.9 \mathrm{~d}$ in lactation, producing $27.5 \pm 5.0 \mathrm{~kg} / \mathrm{cow}$ of milk and with $3.1 \pm 1.8$ lactations were evaluated (means \pm standard error of the means). Cows were allocated into 4 treatments: control $(\mathrm{CON})$, without plant extracts in the diet; oregano extract (OR), with the addition of $0.056 \%$ of oregano extract in the dry matter (DM) of the diet; green tea (GT), with the addition of $0.028 \%$ of green tea extract in the DM of the diet; and mixture, with the addition of $0.056 \%$ oregano extract and $0.028 \%$ green tea extract in the DM of the diet. The forage-to-concentrate ratio was 60:40. Forage was composed of corn silage (94\%) and Tifton hay $(6 \%)$; concentrate was based on ground corn and soybean meal. Plant extracts were supplied as powder, which was previously added and homogenized into $1 \mathrm{~kg}$ of concentrate in natural matter, top-dressed onto the total mixed diet. No treatment by day interaction was observed for any of the evaluated variables, but some block by treatment interactions were significant. In Holstein cows, the mixture treatment decreased gross
\end{abstract}

Received September 14, 2017.

Accepted January 16, 2018.

${ }^{1}$ Corresponding author: vivinha.fischer@hotmail.com energy and tended to decrease the total-tract apparent digestibility coefficient for crude protein and total digestible nutrients when compared with OR. During the gas measurement period, GT and OR increased the digestible fraction of the ingested DM and decreased $\mathrm{CH}_{4}$ expressed in grams per kilogram of digestible DMI compared with CON. The use of extracts did not change rumen $\mathrm{pH}$, total volatile fatty acid concentration, milk yield, or most milk traits. Compared with CON, oregano addition decreased fat concentration in milk. The use of plant extracts altered some milk fatty acids but did not change milk fatty acids grouped according to chain length (short or long), saturation (unsaturated or saturated), total conjugated linoleic acids, and n-3 and n-6 contents. Green tea and oregano fed separately reduced gas emission in cows during the first third of lactation and have potential to be used as feed additives for dairy cows.

Key words: catechin, essential oil, methane emission, milk composition

\section{INTRODUCTION}

As the use of some feed additives such as ionophores have been banned in many countries, several plant extracts have been studied due to their potential as rumen fermentation modifiers and their antimicrobial and antioxidant activities (Lauzon et al., 2005; Lejonklev et al., 2016; Oh and Hristov, 2016). Organic compounds derived by the secondary metabolism of plants can present therapeutic functions (Oh et al., 2017). Isolated components from different plant extracts may show additive effects when mixed and used to supplement the diet of animals (Benkeblia, 2004).

Green tea (Camellia sinensis L.) is a source of polyphenols, mainly catechins (Crespy and Williamson, 2004), but also contains saponins, caffeine, and 
L-theanine. It may present antioxidant, antimicrobial, anticoccidial, and antiprotozoal activities (Heleno et al., 2015). Oregano (Origanum vulgare) is a source of essential oils such as carvacrol and thymol. Polyphenols and essential oils may modify rumen fermentation (Lin et al., 2013; Heleno et al., 2015) and affect methanogenesis, inhibiting growth, development, activity, and metabolism of the methanogenic Archaea, directly or indirectly (Szumacher-Strabel and Cieślak, 2012), and may mitigate $\mathrm{CH}_{4}$ emissions.

Reducing $\mathrm{CH}_{4}$ emissions without losses in animal production has been a challenge and has mobilized several researchers (Knapp et al., 2014). The greenhouse gas $\mathrm{CH}_{4}$ is 28 times more potent than $\mathrm{CO}_{2}$ in causing global warming (IPCC, 2014). Lowering $\mathrm{CH}_{4}$ emissions can reduce between 2 to $12 \%$ of animal energy losses (Johnson and Johnson, 1995), although evidence is limited about positive effects on animal growth, reproduction, and production of milk and meat (Benchaar et al., 2008; Cobellis et al., 2016; Oh et al., 2017).

Based on previous reports (Eruden et al., 2005; Lauzon et al., 2005; Hristov et al., 2013; Winkler et al., 2015), it is expected that the use of oregano and green tea extracts reduce methane emissions from lactating cows, but without major effects on digestibility, milk production, and composition. However, the great variety of compounds and dosages used has made it difficult to produce a meaningful compilation of the research results (Cobellis et al., 2016; Oh et al., 2017). Furthermore, most data in the literature are based on in vitro studies (Cobellis et al., 2016; Oh et al., 2017) or were short-term trials, which made the use of these natural additives uncertain at a farm level, requiring further research aiming to reproduce the results in vivo, especially for dairy cows (Benchaar et al., 2008; Oh et al., 2017). Our hypotheses are that (1) oregano extract will reduce methane metrics and will not have a negative effect on animal production; (2) green tea extracts will reduce methane metrics and will not have a negative effect on animal production; (3) oregano and green tea extract when fed in association will present an additive effect in reducing methane metrics. This study aimed to evaluate the use of oregano extract, green tea extract, and their association as feed additives on performance and methane emissions of dairy cows between 28 and $87 \mathrm{~d}$ of lactation.

\section{MATERIALS AND METHODS}

\section{Location Description, Animals, and Management}

This study was approved by the Ethics Committee for the Use of Farm Animals from the Universidade
Federal do Rio Grande do Sul, protocol number 18.510. The experiment was conducted at the Experimental Station José Henrique Bruschi of Embrapa Gado de Leite, Coronel Pacheco, Minas Gerais, Brazil (latitude $21^{\circ} 35^{\prime} 16^{\prime \prime}$, longitude $43^{\circ} 15^{\prime} 56^{\prime \prime}$, and $484 \mathrm{~m}$ above sea level) for $58 \mathrm{~d}$, with the first $14 \mathrm{~d}$ for the adaptation period and the subsequent $44 \mathrm{~d}$ for the experiment.

Thirty-two lactating cows blocked by genetic group (16 Holstein cows and 16 crossbred Holstein-Gir) were distributed within 4 groups of 8 animals (4 Holstein and 4 crossbred Holstein-Gir per treatment) considering their BW, DIM, parity, and previous milk production.

Treatments were control $(\mathbf{C O N})$, without plant extracts in the diet; oregano extract (OR), with the addition of $0.056 \%$ of oregano extract in the DM of the diet; green tea $(\mathbf{G T})$, with the addition of $0.028 \%$ of green tea extract in the DM of the diet; and mixture (MIX), with the addition of $0.056 \%$ oregano extract and $0.028 \%$ green tea extract in the DM of the diet.

At the beginning of the trial, cows in the CON treatment averaged ( \pm SEM): $529.8 \pm 51.2 \mathrm{~kg}$ of BW, 60.7 \pm 22.0 DIM, $28.2 \pm 7.5 \mathrm{~kg}$ of milk yield, and $3.1 \pm 1.7$ lactations; in the GT treatment cows averaged $( \pm$ SEM) $519.7 \pm 51.8 \mathrm{~kg}$ of BW, $59.3 \pm 21.4$ DIM, $21.2 \pm 3.7 \mathrm{~kg}$ of milk yield, and $3.6 \pm 2.3$ lactations; cows in the OR treatment averaged $( \pm \mathrm{SEM}) 526.2 \pm 74.6 \mathrm{~kg}$ of $\mathrm{BW}$, $55.5 \pm 21.3$ DIM, $28.2 \pm 3.5 \mathrm{~kg}$ of milk yield, $3.1 \pm$ 1.5 lactations and cows in the MIX treatment averaged $( \pm \mathrm{SEM}) 514.4 \pm 71.5 \mathrm{~kg}$ of BW, $53.4 \pm 25.0$ DIM, 25.0 $\pm 4.4 \mathrm{~kg}$ of milk yield, and $3.1 \pm 1.9$ lactations.

Plant extracts were given to the animals as powder, homogenized in $1 \mathrm{~kg}$ (as fed) of concentrate top-dressed onto the total mixed diet at the time of feeding. Oregano extract (Orego Stim, Meriden Animal Health Limited, Northampton, UK, redistributed in Brazil by Advet Animal Nutrition) had a minimum concentration of 50 $\mathrm{g} / \mathrm{kg}$, containing 80 to $82 \%$ of carvacrol, 2.5 to $3.0 \%$ of thymol, 3.5 to $9.0 \%$ of p-cymene, and 2.0 to $5.0 \%$ of Y-terpinene. Green tea extract had an approximate concentration of $56 \%( \pm 2.5 \%)$ of polyphenols. During the adaptation period $(14 \mathrm{~d})$, all animals were fed the same basal diet, without plant extracts, receiving one of the treatments from d 15 .

Cows were milked twice a day, at 0600 and $1430 \mathrm{~h}$, and were housed in freestall barns by treatment. The total diet was individually supplied once a day in automatic feeding troughs, at $0830 \mathrm{~h}$, allowing 5 to $10 \%$ of refusals. In each trough, $1 \mathrm{~kg}$ of concentrate containing or not containing the plant extracts was top-dressed on the total mixed diet.

The TMR fed to the cows were identical, except for the added plant extracts. Total diet was formulated to meet the nutritional requirements for $30 \mathrm{~kg}$ of milk 
production with $3.8 \%$ of fat (NRC, 2001). The forageto-concentrate ratio was 60:40, with forage composed of corn silage (94\%) and Tifton (Cynodon dactylon) hay $(6 \%)$. The concentrate was formulated with ground corn $(43.6 \mathrm{~kg} / 100 \mathrm{~kg})$, soybean meal with $46 \%$ of CP $(47.9 \mathrm{~kg} / 100 \mathrm{~kg})$, the mineral salt Guabiphos Lactage Gold $(4.3 \mathrm{~kg} / 100 \mathrm{~kg}$, Guabi Nutrição e Saúde Animal S.A, Campinas, SP, Brazil), sodium bicarbonate (1.4 $\mathrm{kg} / 100 \mathrm{~kg}$ ), limestone (1.1 kg/100 kg), magnesium oxide $(0.7 \mathrm{~kg} / 100 \mathrm{~kg})$, ammonium sulfate $(0.6 \mathrm{~kg} / 100 \mathrm{~kg})$, and urea $(0.4 \mathrm{~kg} / 100 \mathrm{~kg})$.

Diet and orts were collected, weighed, and sampled daily at the time of the morning milking and further pooled on a weekly basis. Samples of ingredients, TMR, and refusals were analyzed for DM (Detmann et al., 2012; method INCT-CA no. G-003/1), nitrogen (Kjeldahl method, nitrogen content was then multiplied by 6.25 to calculate CP), ether extract (Soxhlet method), NDF (Van Soest et al., 1991), ADF (Robertson and Van Soest, 1981), lignin (Van Soest and Robertson, 1985), and gross energy (calorimetric method) contents (AOAC International, 2011; Table 1).

Live BW and BCS evaluations were made weekly after the morning milking. An electronic scale was used for weighing and the BCS was evaluated on a 1 to 5 scale, according to Wildman et al. (1982).

\section{Dry Matter Intake}

Daily DMI was evaluated directly, as the difference between the amount of food supplied and the amount of orts left in the trough, using electronic Calan gates (American Calan Inc., Northwood, NH). The CP, NDF, ADF, TDN, and gross energy intakes were calculated as well.

\section{Measurement of Fecal Output}

Fecal samples were taken from the rectum of the animals after morning and afternoon milking from d 54 to 58. The samples were dehydrated, ground, and sieved through 1-mm screen sieve, with samples analyzed for $\mathrm{DM}, \mathrm{CP}, \mathrm{NDF}, \mathrm{ADF}$, ether extract, lignin, and gross energy contents (AOAC International, 2011).

\section{Total-Tract Apparent Total Digestibility}

The indigestible NDF was used to calculate digestibility. The indigestible NDF content of feed and feces was determined from samples ground and sieved through a $2-\mathrm{mm}$ screen sieve, followed by $288 \mathrm{~h}$ of in situ incubation using F57 bags (Ankom Technology, Macedon, NY; Valente et al., 2011).

Table 1. Dietary ingredients and chemical composition of TMR fed to the cows during the trial

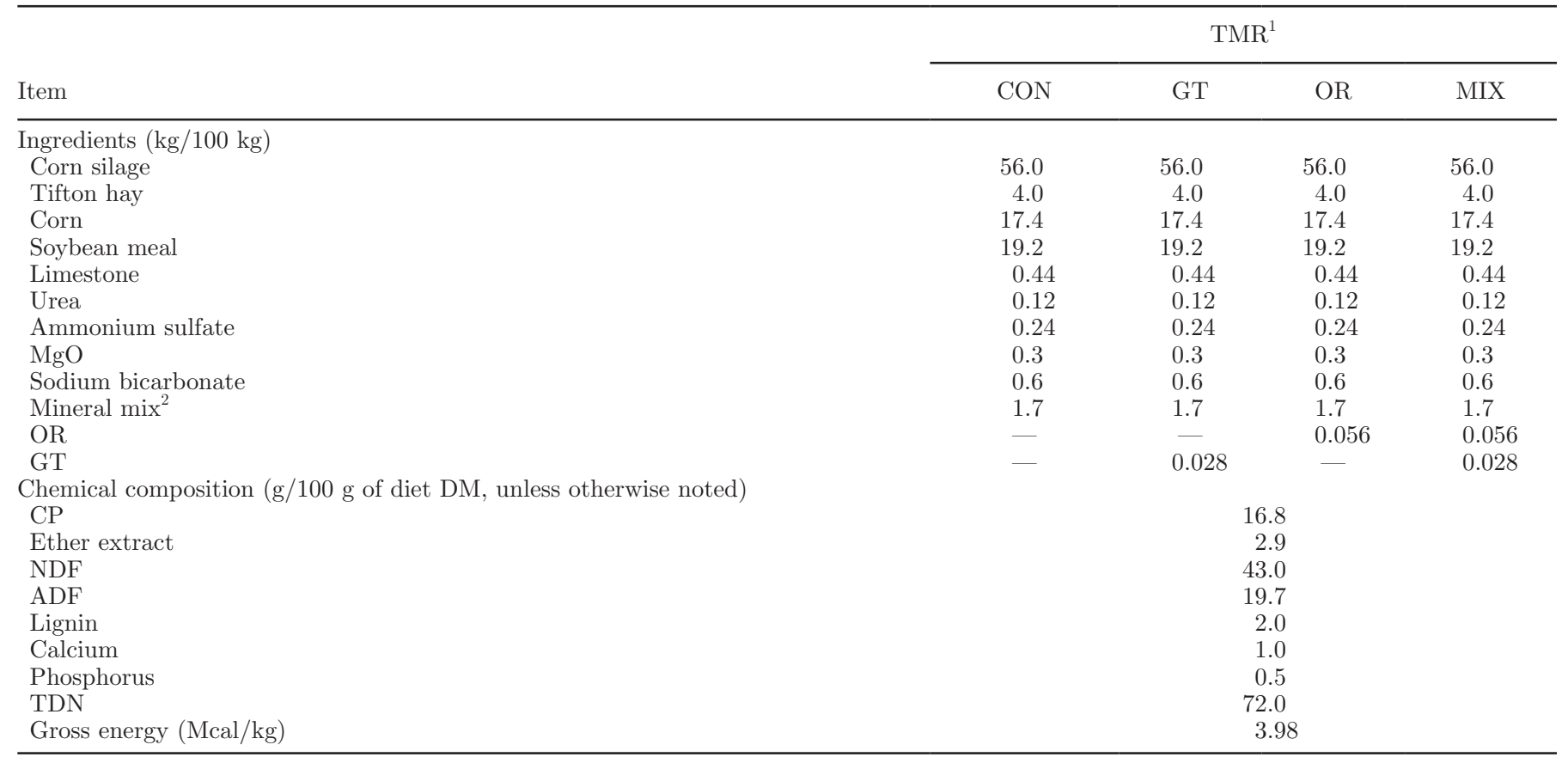

${ }^{1} \mathrm{CON}=$ control; $\mathrm{GT}=5 \mathrm{~g} / \mathrm{d}$ of green tea extract; OR $=10 \mathrm{~g} / \mathrm{d}$ of oregano extract; MIX $=10 \mathrm{~g} / \mathrm{d}$ of OR $+5 \mathrm{~g} / \mathrm{d}$ of GT.

${ }^{2}$ Guabiphos Lactage Gold. Guabi Nutrição e Saúde Animal S.A, Campinas, SP, Brazil. 


\section{Milk Production and Physical-Chemical Composition}

Milk production $(\mathrm{kg})$ was recorded every day at the morning and evening milking during the experimental period using a DeLaval milk meter MM25 (Kansas City, MO). Once a week, milk samples, as proportional mixtures of morning and evening milk, were analyzed for stability in the alcohol test (from 72 to $86^{\circ} \mathrm{GL}$ concentrations; vol/vol), $\mathrm{pH}$, and acidity $\left({ }^{\circ} \mathrm{D}\right)$ as described by Tronco (2013). Fat, lactose, protein, TS extracts, and urea concentrations were determined by infrared spectrophotometry (Fonseca and Santos, 2000).

Milk production data were corrected for energy (ECM), as the values corrected for $3.5 \%$ fat and $3.2 \%$ true protein, using the formula $\mathrm{ECM}=[(0.3246 \times \mathrm{kg}$ of milk $)+(12.86 \times \mathrm{kg}$ of fat $)+(7.04 \times \mathrm{kg}$ of true protein)], with true protein calculated as $95 \%$ of the milk CP (NRC, 2001).

Proportional mixtures of morning and evening milk from d 57 were collected from each cow were collected and frozen for further analysis of the fatty acid profile. The milk samples were thawed at room temperature and a 1-mL aliquot was used for fat extraction using a mixture of diethyl ether and hexane according to a reference procedure (AOAC International, 2011). The organic phase containing the milk fat $(\sim 20 \mathrm{mg})$ was evaporated to dryness at $40^{\circ} \mathrm{C}$ under an oxygen and nitrogen free atmosphere. Fatty acid methyl esters were obtained by base-catalyzed transmethylation (Baldin et al., 2013). Fatty acid methyl esters were quantified by a gas chromatograph (model 7820-A, Agilent Technologies, Santa Clara, CA) fitted with a flameionization detector and equipped with a CP-Sil 88 fused-silica capillary column $(100 \mathrm{~m} \times 0.25 \mathrm{~mm} \times 0.2$ $\mu \mathrm{m}$ film thickness; Varian Inc., Palo Alto, CA). Operating conditions were as described by Cruz-Hernandez et al. (2007). Peaks were identified by retention time comparisons with a commercial standard containing a mixture of FAME (Supelco 37 Component FAME Mix, Sigma-Aldrich). The FAME were identified by comparison of retention times with commercial FAME standards; minor trans/cis-C18:1 isomers and trans-9 cis-11 CLA were identified according to their order of elution reported under the same GC conditions (Baldin et al., 2013). Milk fatty acid composition was expressed as a weight percentage of total fatty acids using theoretical relative response factors (Wolff et al., 1995).

\section{Respiration Chamber Measurements}

After the digestibility trial, a respiration chamber was used to measure $\mathrm{O}_{2}$ consumption, $\mathrm{CH}_{4}, \mathrm{CO}_{2}$ emissions, and heat production using 5 cows per treatment. Cows entered in the chamber in a randomized order. Each animal was held in the chamber for $22 \mathrm{~h}$ per day, on 2 separate days, leaving for milking and for cleaning the chambers as well as calibrations of the equipment. The heat production was calculated according to Brouwer (1965).

The open-circuit system was adopted for the measurements (Machado et al., 2016). Two pairs of chambers were used (3.68 m long, $2.56 \mathrm{~m}$ wide, and $2.24 \mathrm{~m}$ high), with controlled climate, maintaining temperature and humidity in the range of 5 to $45^{\circ} \mathrm{C}$ and 30 to $80 \%$, respectively. The chambers had windows on both sides to allow the animals to keep visual contact with the external area. For the animals' security, each chamber was equipped with an emergency hatch, closed by a magnet, that could automatically open in case of energy failure, floods, extreme temperature, or $\mathrm{CO}_{2}$ in excess.

An air outlet with a filter box (CSL-851-200HC, Solberg Manufacturing Inc., Itasca, IL) was part of each chamber, with the air being continuously drawn into the chamber by a sealed rotary pump connected to a mass flow regulator (FlowKit model FK-500, Sable Systems International, Las Vegas, NV). Air from all chambers and a sample of environmental air were analyzed for $\mathrm{O}_{2}, \mathrm{CO}_{2}$, and $\mathrm{CH}_{4}$ concentrations; monitoring occurred in a cyclic period of $20 \mathrm{~min}$. The analyzers were calibrated daily and the chambers' recovery values were 99 and $98 \%$ for $\mathrm{CO}_{2}$ and $\mathrm{CH}_{4}$, respectively.

Calibration of the $\mathrm{CO}_{2}$ and $\mathrm{CH}_{4}$ analyzers (zero and span) was made daily before the beginning of each measurement. The $\mathrm{O}_{2}$ and water vapor analyzers were calibrated once a week. For zeroing the $\mathrm{CO}_{2}, \mathrm{CH}_{4}$, and $\mathrm{O}_{2}$ analyzers, nitrogen gas (99.999\%) was used, and for span calibration of $\mathrm{CO}_{2}$ and $\mathrm{CH}_{4}$, a mixed gas was used $\left(0.5 \% \mathrm{CO}_{2}, 0.1 \% \mathrm{CH}_{4}\right.$ in $\mathrm{N}_{2}$ as carrier). The $\mathrm{O}_{2}$ analyzer was calibrated with dry ambient air, scrubbed from water using magnesium perchlorate because it shows an almost constant concentration of $20.95 \%$ of $\mathrm{O}_{2}$. A zero value of the water vapor analyzer was achieved with the dry air, and span value was calculated following the Lighton (2008) equation: WVP $=\mathrm{BP} \times\left[\left(\mathrm{F}^{\prime} \mathrm{iO}_{2}-\right.\right.$ $\left.\left.\mathrm{FiO}_{2}\right) / \mathrm{F}^{\prime} \mathrm{iO}_{2}\right]$, where WVP is the water vapor pressure in the same units as barometric pressure $(\mathrm{kPa}) ; \mathrm{BP}$ is the barometric pressure; and $\mathrm{F}^{\prime} \mathrm{iO}_{2}$ and $\mathrm{FiO}_{2}$ are $\mathrm{O}_{2}$ fractional concentrations of dry and wet ambient air, respectively.

A recovery test of the whole system was made immediately before the beginning of the trial (same week) by injection of known volumes of $\mathrm{CO}_{2}(99.999 \%)$ and $\mathrm{CH}_{4}(99.995 \%)$ in each chamber, using a portable mass flowmeter with totalizer function (MC-50SLPM-D, Alicat Scientific Inc., Tucson, AZ).

Data acquisition and analysis were performed by the Metasys (version 5.1.3.0400, Johnson Controls Inc., 
Milwaukee, WI) software that allows the calculation of the rate of $\mathrm{O}_{2}$ consumption and of $\mathrm{CO}_{2}$ and $\mathrm{CH}_{4}$ production.

\section{Volatile Fatty Acids}

Ruminal contents were sampled at the end of digestibility trial and $4 \mathrm{~h}$ after the feeding using a stomach tube and the initial $200 \mathrm{~mL}$ of collected fluid were discarded, to avoid saliva contamination. Because of the collection method, samples taken from the rumen represented the liquid phase of ruminal content. A sample of approximately $60 \mathrm{~mL}$ was filtered through 4 layers of cheesecloth and split into 3 aliquots then frozen at $-80^{\circ} \mathrm{C}$ until analysis. These samples were thawed at room temperature $\left(25^{\circ} \mathrm{C}\right)$, centrifuged $(12,000 \times g, 10$ min, $5^{\circ} \mathrm{C}$ ) and the cell-free supernatants were analyzed as described by Siegfried et al. (1984). Briefly, the samples were analyzed for VFA concentration by HPLC in a Dionex Ultimate 3000 Dual Detector HPLC (Dionex Corporation, Sunnyvale, CA) coupled to a Shodex RI101 refractive index detector maintained at $40^{\circ} \mathrm{C}$ using a Phenomenex Rezex ROA ion exchange column, 300 $\times 7.8 \mathrm{~mm}$, maintained at $45^{\circ} \mathrm{C}$. The mobile phase was prepared with $5 \mathrm{mmol} / \mathrm{L}$ of sulfuric acid $\left(\mathrm{H}_{2} \mathrm{SO}_{4}\right)$ and the flow was $0.7 \mathrm{~mL} / \mathrm{min}$. The following VFA were used for the calibration of the standard curve: acetic, succinic, formic, propionic, valeric, isovaleric, isobutyric, and butyric acid. All acids were prepared with a final concentration of $10 \mathrm{mmol} / \mathrm{L}$, except isovaleric acid (5 $\mathrm{mmol} / \mathrm{L})$ and acetic acid (20 $\mathrm{mmol} / \mathrm{L})$.

\section{Experimental Design and Statistical Analysis}

Data were analyzed considering the randomized complete block design with 4 replicates per block. Most data were analyzed considering 4 cows per block except for production of gases and VFA in the rumen, considering 2 replicates for block 1 and 3 replicates for block 2. Data collected over time were subjected to a repeated measurements ANOVA, whereas mean values were analyzed according to a main effects ANOVA with treatment and block as main effects, using PROC MIXED procedures of SAS, version 9.4 (SAS Institute Inc., Cary, NC). We considered the fixed effects of block ( $\mathrm{n}=2$ genetic groups), treatment $(\mathrm{n}=4)$, days of evaluations, and their interactions (treatment by measurement day and treatment by block). Animal and the residue were considered as the random effects. In both models, parity, DIM, BW, and milk production at the beginning of the trial (but before treatments were initiated) were included in the model as covariates. A structural selection test was performed using the Bayesian information criterion (BIC). Covariance structures tested were compound symmetry, first-order autoregressive, Toeplitz, and unstructured. The first and the second hypotheses comparing the inclusion of oregano or green tea with the control diet were tested using the contrasts $\mathrm{CON} \times \mathrm{OR}$ and $\mathrm{CON} \times \mathrm{GT}$ with adjusted 1-tailed side Dunnett $P$-values, respectively. The third hypothesis about the additive effect of adding both extracts comparing with the addition of the extracts separately was tested using 2 contrasts: GT $\times$ MIX and OR $\times$ MIX with adjusted 1-tailed side Dunnett $P$-values, highlighting the additive effect of OR and GT, respectively. All variables were previously submitted to the normality test. Methane emissions per kilogram of ingested OM, per kilogram of ingested digestible NDF and milk fatty acids C18:1 trans-10, C18:2 trans-9,trans-12, and C18:2 cis-9,cis-12 were logarithmically transformed before being statistically analyzed. The SCC, ethanolic stability, and milk fatty acids C14:0, C16:0, C18:0 iso, and CLA trans-10,cis-12 were analyzed by nonparametric statistics using the Wilcoxon test because they did not show normal distribution even after being transformed. The significant differences were declared when $P<0.05$ and a trend if $0.05<P<0.10$.

\section{RESULTS}

The treatment by day interaction was not significant $(P>0.10)$ for any of the variables evaluated in this study. The block by treatment interaction was significant $(P<0.05)$ for total-tract apparent digestibility coefficients of DM (DMd) and gross energy (GEd), pH, protein content, and some fatty acids of milk. These results will be further detailed in the text.

The use of plant extracts did not affect the following variables: $\mathrm{BW}, \mathrm{BCS}$, and the voluntary intakes of gross energy, ADF, NDF, CP, and TDN. The MIX treatment tended to decrease DMI $(P<0.10)$ when compared with GT (Table 2).

In Holstein cows, MIX tended to decrease DMd $(P$ $<0.10)$ and decreased GEd $(P<0.05)$ when compared with OR (Table 3). Overall, compared with CON, OR tended to increase the total-tract apparent digestibility coefficient for CP, whereas MIX tended to present a decrease in total-tract apparent digestibility coefficient for CP and TDN compared with OR $(P<0.10)$.

The MIX decreased $(P<0.05)$ the molar proportion of acetate when compared with GT and OR and tended to decrease the acetate-to-propionate ratio (expressed as molar proportion of total VFA) in ruminal fluid when compared with OR. The MIX tended to increase the molar proportion of butyrate $(P<0.10)$ when compared with GT and OR. Plant extracts did not influence total VFA concentration and propionate 

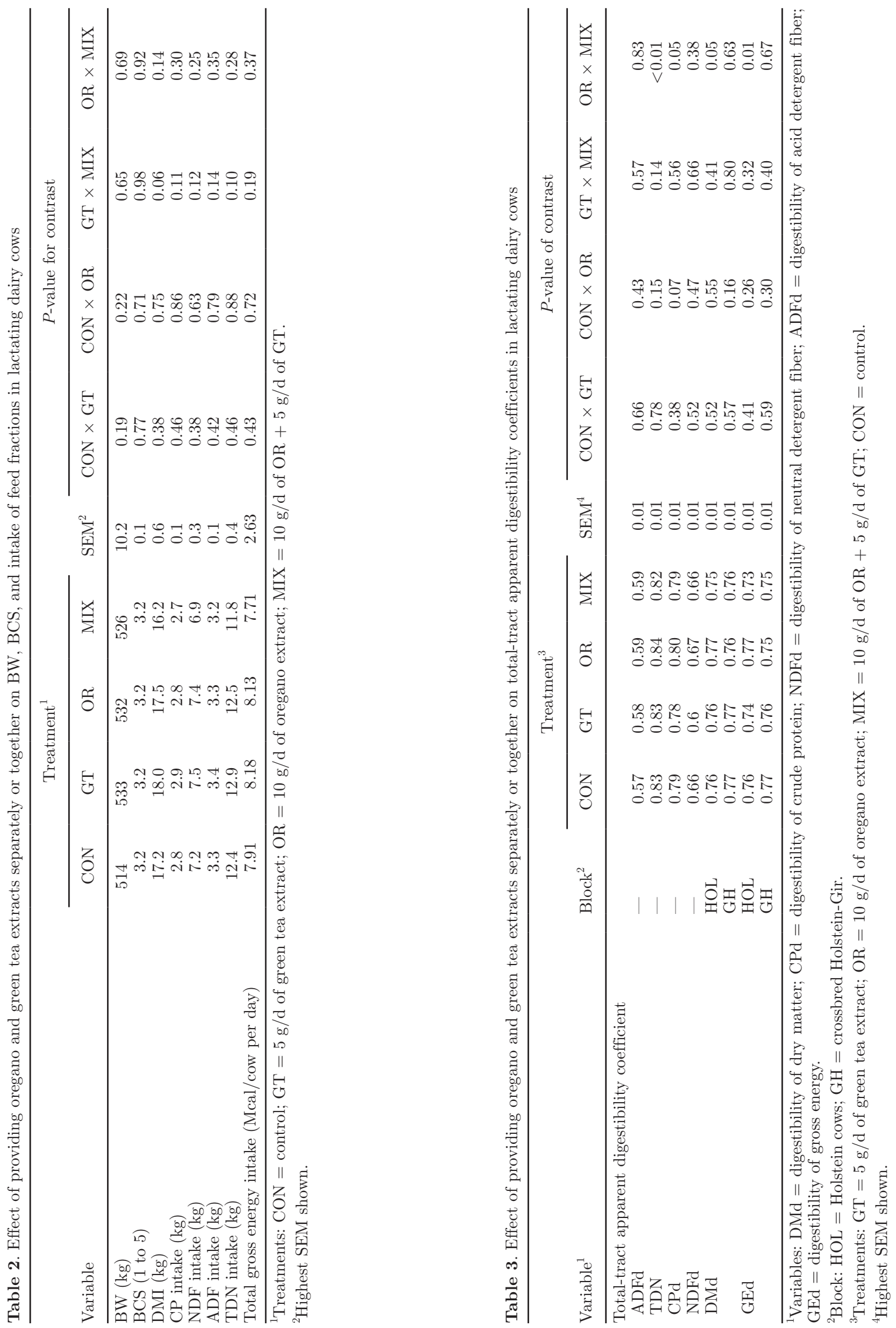
Table 4. Effect of providing oregano and green tea extracts separately or together on ruminal parameters in lactating dairy cows

\begin{tabular}{|c|c|c|c|c|c|c|c|c|c|}
\hline Ruminal parameter ${ }^{1}$ & \multicolumn{4}{|c|}{ Treatment $^{2}$} & $\mathrm{SEM}^{3}$ & \multicolumn{4}{|c|}{$P$-value of contrast } \\
\hline Total VFA $(\mu \mathrm{mol} / \mathrm{mL})$ & 52.3 & 43.0 & 61.7 & 29.4 & 13.9 & 0.68 & 0.67 & 0.48 & 0.11 \\
\hline Propionate $(\mu \mathrm{mol} / 100 \mu \mathrm{mol})$ & 21.6 & 20.4 & 19.4 & 21.7 & 1.9 & 0.68 & 0.88 & 0.50 & 0.19 \\
\hline Butyrate $(\mu \mathrm{mol} / 100 \mu \mathrm{mol})$ & 14.9 & 16.3 & 16.0 & 19.5 & 1.5 & 0.75 & 0.56 & 0.07 & 0.05 \\
\hline $\mathrm{pH}$ & 7.3 & 7.5 & 7.1 & 7.6 & 0.3 & 0.58 & 0.53 & 0.92 & 0.15 \\
\hline
\end{tabular}

${ }^{1}$ Total VFA was calculated as the sum of acetate, propionate, and butyrate. Acetate, propionate, and butyrate expressed as a molar proportion of total VFA.

${ }^{2}$ Treatments: $\mathrm{CON}=$ control; GT $=5 \mathrm{~g} / \mathrm{d}$ of green tea extract; OR $=10 \mathrm{~g} / \mathrm{d}$ of oregano extract; $\mathrm{MIX}=10 \mathrm{~g} / \mathrm{d}$ of OR $+5 \mathrm{~g} / \mathrm{d}$ of $\mathrm{GT}$.

${ }^{3}$ Highest SEM shown.

(expressed as a molar proportion of total VFA) as well as ruminal fluid $\mathrm{pH}(P>0.05$; Table 4$)$.

In wk 8 , during the gas measurement period, oregano inclusion tended $(P<0.10)$ to increase DMI; green tea and oregano inclusion increased $(P<0.05)$ the digestible fraction of the ingested DM (dDMI). Regarding methane metrics, green tea and oregano decreased methane emissions expressed in grams per kilogram of dDMI compared with CON $(P<0.05)$. Oregano extract tended $(P<0.10)$ to decrease methane emission expressed in grams per kilogram of DMI. No differences $(P \geq 0.10)$ were observed between dietary treatments containing oregano or green tea extracts (or both) compared with $\mathrm{CON}$ for the following variables: milk yield, $\mathrm{O}_{2}$, and $\mathrm{CH}_{4}$ expressed in liters per kilogram of $\mathrm{BW}^{0.75}$, heat production $\left(\mathrm{kcal} / \mathrm{kg}\right.$ of $\left.\mathrm{BW}^{0.75}\right)$, digestible fraction of the ingested $\mathrm{NDF}$, and $\mathrm{CH}_{4}$ expressed in grams per day (Table 5).
Concerning milk metrics measured over the whole trial, some block by treatment interactions were detected. For the Holstein-Gir crossbred cows, OR and GT increased the protein percentage in milk compared with CON $(P<0.05)$. Also, compared with CON, OR decreased $(P<0.05)$ fat concentration and tended $(P<$ $0.10)$ decrease fat-to-protein ratio. The MIX decreased the protein content of milk of Holstein-Gir crossbred cows apparently due to both OR and GT inclusion. In Holstein cows, OR tended to increase $\mathrm{pH}$ compared with CON $(P<0.10$; Table 6$)$.

Overall inclusion of plant extracts into the diet did not change $(P \geq 0.10)$ milk yield, milk production efficiency, and most of milk traits such as lactose, urea nitrogen, TS extract, dry nonfat extract, ethanolic stability, and acidity. Compared with CON, OR decreased fat content in milk $(P<0.05)$ and tended $(P<0.10)$ to decrease the fat-to-protein ratio in milk.

Table 5. Effect of providing oregano and green tea extracts separately or together on productive variables, gas exchange, and heat production in lactating dairy cows during the respiratory chamber measurement period

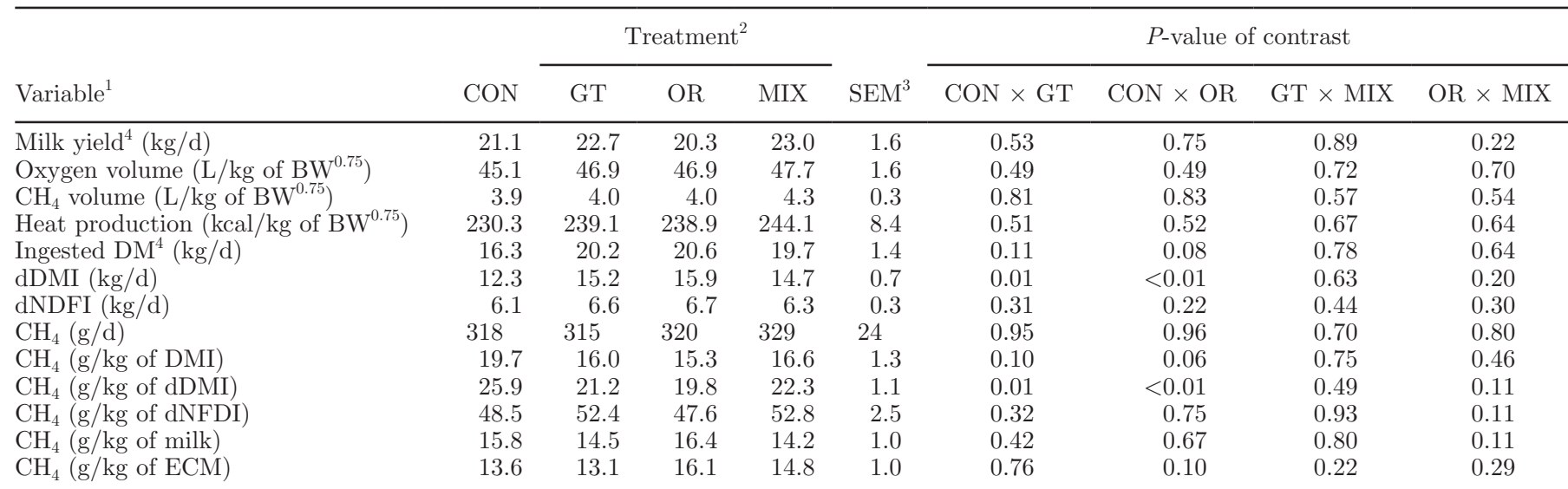

${ }^{1} \mathrm{dDMI}=$ digestible dry matter ingested; dNDFI $=$ digestible neutral detergent fiber ingested; $\mathrm{BW}^{0.75}=$ metabolic $\mathrm{BW}$.

${ }^{2}$ Treatments: $\mathrm{CON}=$ control; GT $=5 \mathrm{~g} / \mathrm{d}$ of green tea extract; OR $=10 \mathrm{~g} / \mathrm{d}$ of oregano extract; MIX $=10 \mathrm{~g} / \mathrm{d}$ of OR $+5 \mathrm{~g} / \mathrm{d}$ of GT.

${ }^{3}$ Highest SEM shown.

${ }^{4}$ These traits were measured during period where cows stayed in the respiratory chambers. 
KOLLING ET AL.

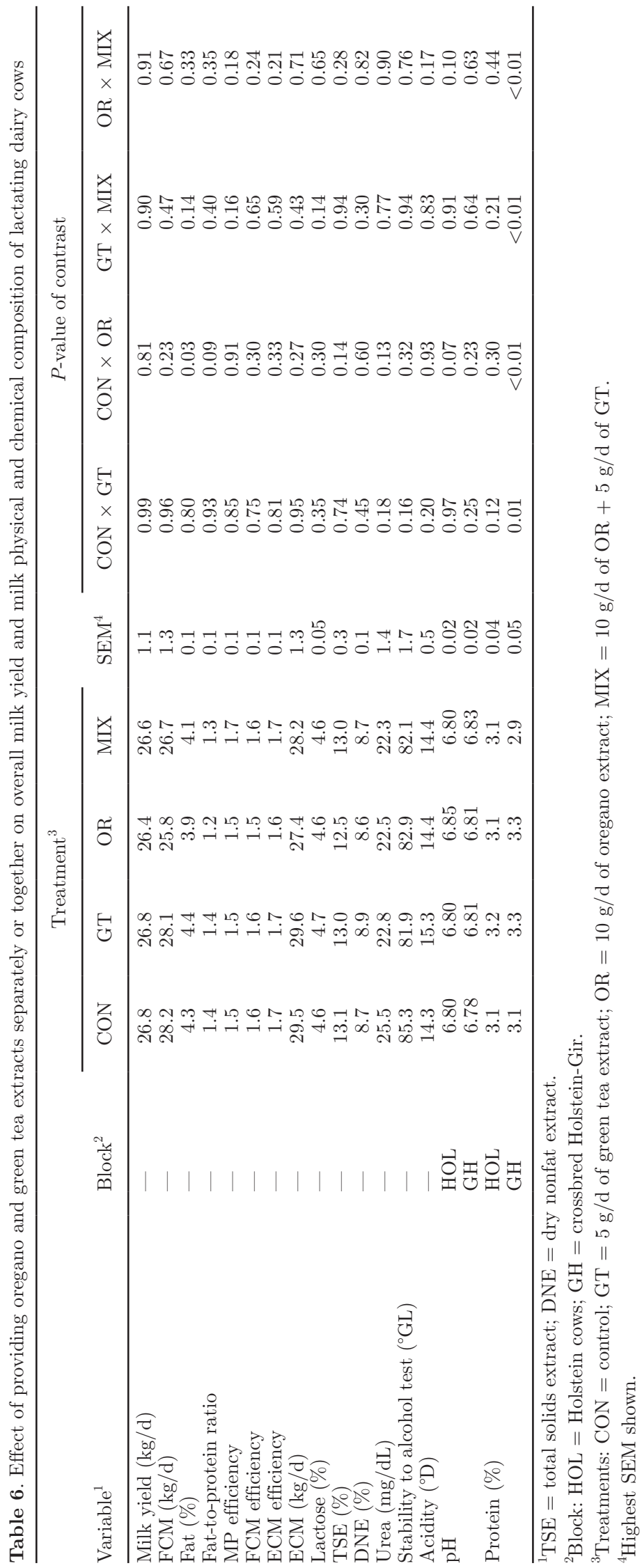


Plant extracts fed separately or in association did not influence $(P \geq 0.10)$ the total concentrations of milk fatty acids grouped as short or long chain, unsaturated or saturated, total CLA, n-3, n-6, and unsaturated C18. Block by treatment interactions were significant for some milk fatty acids (Table 7).

For both Holstein and crossbred Holstein-Gir cows, although the magnitude was different for each genetic group, GT and OR decreased the milk concentration of C19:0 + C18:1 cis-15 in comparison to CON $(P<$ $0.05)$, whereas MIX increased its concentration compared with OR and GT fed separately. When compared with GT, MIX increased C18:1 trans- 4 and CLA trans9, cis-11 $(P<0.05)$ and tended to increase C18:1 trans-5 $(P<0.10)$. On the other hand, when compared with OR, MIX increased C18:1 trans- 4 and C18:1 trans-5 milk concentrations $(P<0.05)$. For crossbred HolsteinGir cows, GT also reduced milk concentrations of C18:1 trans-12, C18:3n-6, CLA trans-9,cis-11, C23:0 $(P<$ $0.05)$ and presented a trend to decrease C18:1 trans-10 and C18:1 trans-13,trans-14 $(P<0.10)$.

Compared with CON, GT tended to increase $(P<$ 0.10) the concentration of C18:2 trans-9, cis-12, whereas it decreased $(P<0.05)$ the concentrations of $\mathrm{C} 18: 2$ trans-9,trans-12, C20:0, C21:0, C20:4n-6, and C24:0. Green tea extract tended $(P<0.10)$ to decrease the concentrations of C18:0, C18:1 cis-13, C18:1 trans-16, C20:3n-6, and C20:5n-3.

Oregano extract decreased $(P<0.05)$ C6:0, C8:0, C10:0, C11:0, C12:0, C18:2 trans-9,trans-12, and C21:0 and tended $(P<0.10)$ to decrease $\mathrm{C} 20: 4 \mathrm{n}-6$, but increased $(P<0.05)$ C18:2 trans-9,cis-12 and tended $(P$ $<0.10)$ to increase C17:1 cis-9.

When compared with GT, MIX increased $(P<0.05)$ the concentrations of $\mathrm{C} 14: 0$ iso, C18:1 cis-13, C18:2 trans-9,trans-12, C20:5n-3, and tended to increase the concentrations of $\mathrm{C} 18: 1$ trans-16 $(P<0.10)$. On the other hand, when compared with OR, MIX increased $(P<0.05)$ the concentrations of $\mathrm{C} 6: 0, \mathrm{C} 8: 0, \mathrm{C} 10: 0$, C11:0, C12:0, C14:0 iso, C10:1 cis-9, C18:1 cis-13, C18:2 trans -9 ,trans -12 but decreased $(P<0.05)$ the concentrations of C17:1 cis-9. The MIX also tended to reduce the concentrations of $\mathrm{C} 18: 1$ cis-9, C20:2n-6, and $\mathrm{C} 22: 0$ and tended to increase the concentrations of C20:5n-3 $(P<0.10)$ due to green tea inclusion.

\section{DISCUSSION}

The present study was designed to evaluate oregano extract containing essential oils and green tea extract containing polyphenols as feed additives added separately or in association into the diet of lactating dairy cows. Green tea and oregano have been evaluated separately in previous research, especially as leaves or by-products fed to lactating cows (Eruden et al., 2005; Hristov et al., 2013; Lejonklev et al., 2013, 2016; Lacerda et al., 2014). The present study highlights the existence of few and small additive effects of feeding green tea and oregano extracts together, especially for digestibility coefficients, DMI, molar proportion of acetate and butyrate in relation to total VFA, and acetate-to-propionate ratio, as well as changes in fatty acid profile in milk, and this is the main contribution of the present study.

Researchers worldwide have demonstrated interest in the evaluation of plant extracts for livestock feeding. Because of the high variability of the compounds and dosages used, the results found so far are inconsistent and even contradictory, pointing to the need for further research in vivo to elucidate topics such as the effect of plant extracts on voluntary intake, rumen fermentation, and methane emission (Cobellis et al., 2016). The use of by-products and large amounts of oregano or green tea leaves far from their production areas such as in Eurasia, the Mediterranean region, or subtropical areas of Asia might not be practical or economical.

In vivo studies testing the use of the small doses of oregano extract are still scarce (Cobellis et al., 2016). Some research evaluating the effects of oregano have tested it in a blend along with other essential oils or plant extracts (Lin et al., 2013), or have supplemented oregano leaves to cows in large daily amounts such as 0.25 to $0.75 \mathrm{~kg}$ (Tekippe et al., 2011; Hristov et al., 2011, 2013). In vitro trials using essential oils from oregano showed a reduction in $\mathrm{CH}_{4}$ emissions and DMd (Becker et al., 2013; Roy et al., 2014; Cobellis et al., 2016). A similar situation exists for green tea, where studies report the use of some isolated chemical compound or the use of green tea grounds silage (Eruden et al., 2005; Nishida et al., 2006).

In the current research, we observed that the additive effect of MIX did not improve the digestibility parameters of Holstein cows, negatively affecting DMd and GEd, whereas this influence was not detected in the data from crossbred cows.

In the current research, during the chamber trial, we observed a significant increase for dDMI with OR and GT, which was sufficient enough to reduce $\mathrm{CH}_{4}$ emissions expressed in grams per kilogram of dDMI compared with the control. Diets supplemented with OR and GT separately probably had better nutrient utilization, losing less energy as $\mathrm{CH}_{4}$. Essential oils, such as carvacrol and thymol in oregano and catechins and saponins in green tea, may reduce $\mathrm{CH}_{4}$ emissions by direct negative effects on methanogens, on some bacteria and protozoa that are critical for methanogen metabolism, or by reducing feed fermentation (OheneAdjei et al., 2008; Cobellis et al., 2016). According to 


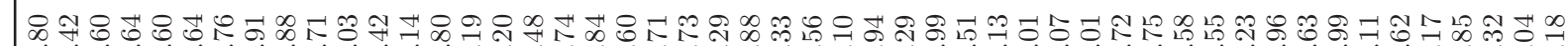

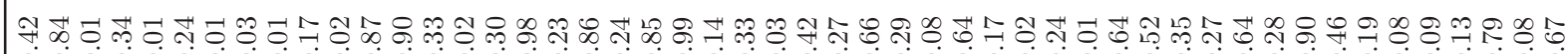
$0000 \mathrm{~V} 00 \dot{\mathrm{V}} 0000000000000000000000000000000000000000000$ $000000000000000000000000000000000 \dot{0} 0000000000000000$

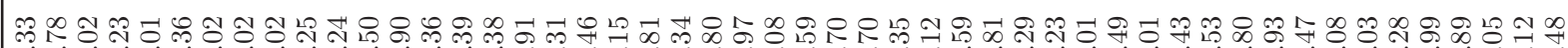
0000000000000000000000000000000000000000000000000

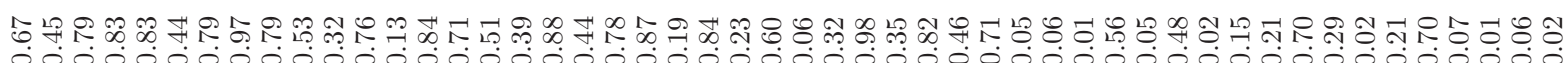
00000000000000000000000000000000000000000000000000

质

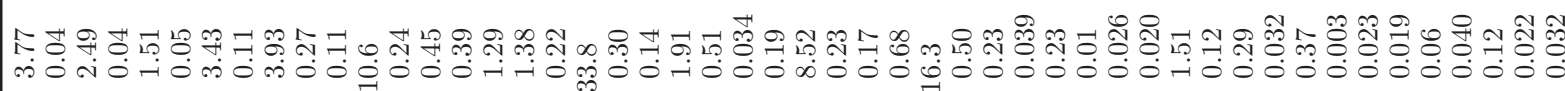

告

U

每

$\frac{-4}{0}$

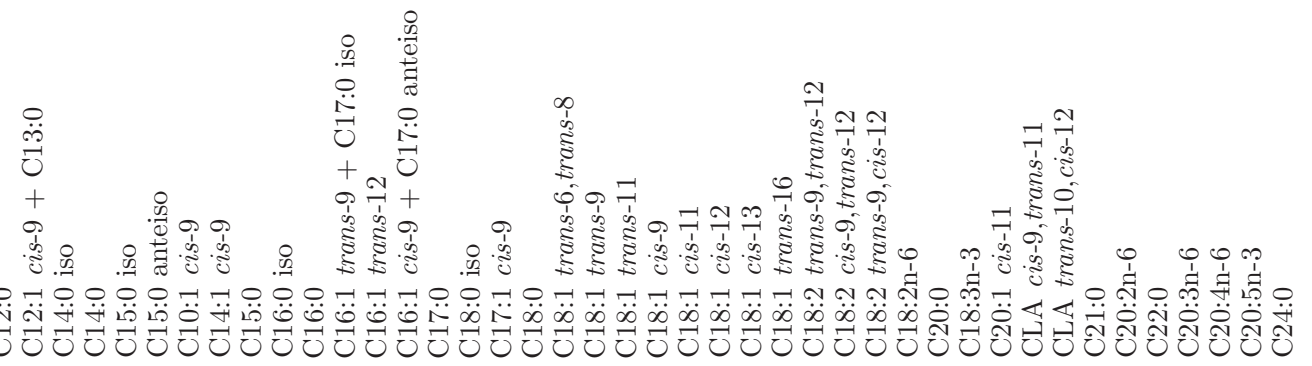




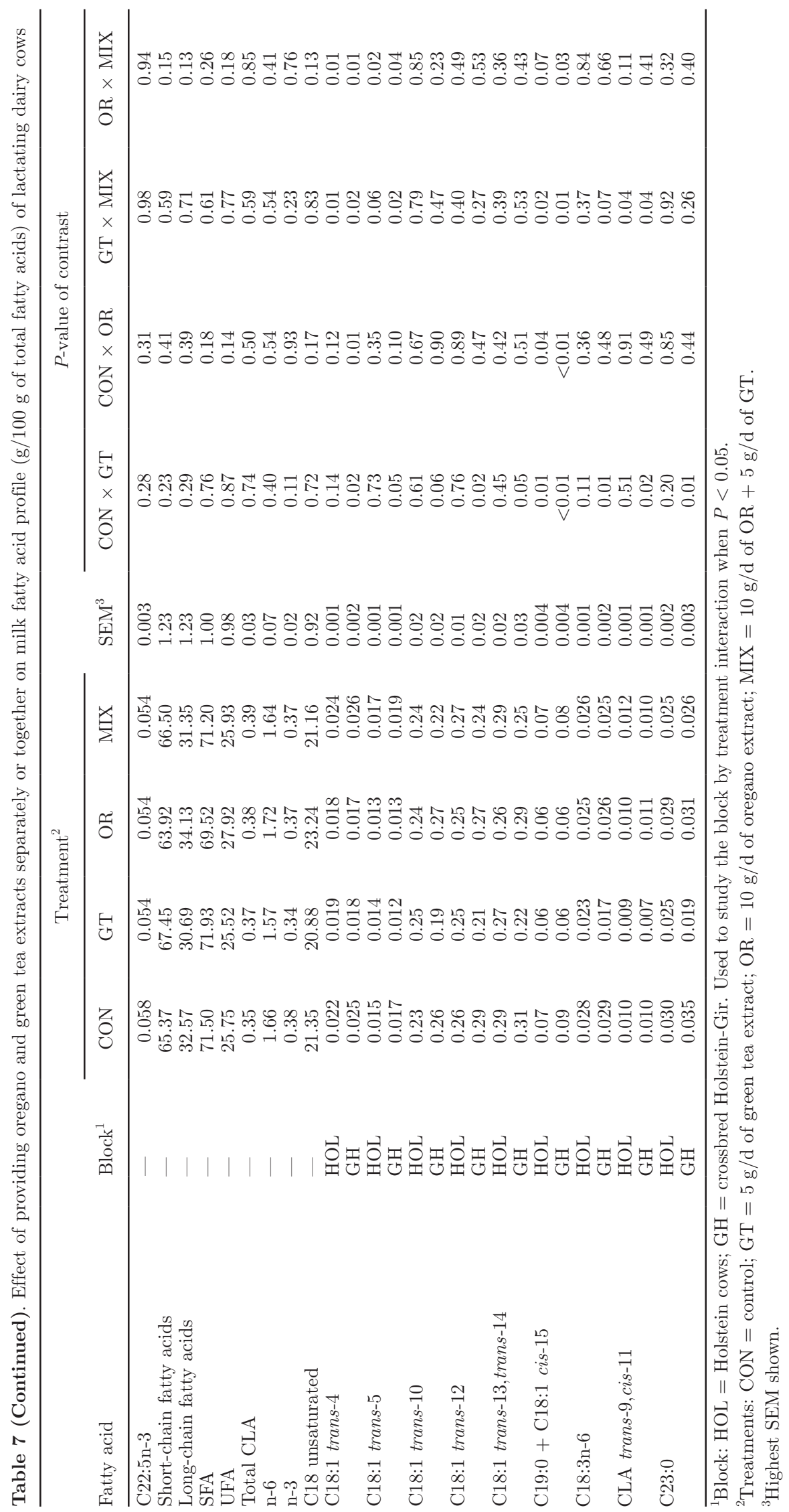


Becker et al. (2013), the catechins present in green tea may act as an efficient anti-reductant and function as a hydrogen sink in the anaerobic and reducing conditions in the rumen. Thus, catechins present in the rumen may compete with methanogens for the residual hydrogen and thus reduce $\mathrm{CH}_{4}$ production. In the present experiment, we postulate that oregano and green tea extracts fed separately may have reduced $\mathrm{CH}_{4}$ emissions $(\mathrm{g} / \mathrm{kg}$ of $\mathrm{dDMI}$ ) because of greater dDMI probably due to antimicrobial activity, or by modifying the abundance of methanogens and other microorganisms related to $\mathrm{CH}_{4}$ production.

The active compounds present in oregano and green tea are able to affect ruminal protein fermentation either by reducing the number of bacteria that are involved with protein degradation and ruminal ammonia production, specifically the hyper-ammonia-producing bacteria (Wallace et al., 2002; Patra, 2012), or by protecting feed protein from being attacked by these microorganisms (Leiber et al., 2012). This may explain the tendency to increase $\mathrm{CP}$ digestibility observed for OR.

The absence of the effect of giving GT and OR separately on the acetate, propionate, butyrate, and total VFA concentrations may indicate that the residual amount of hydrogen did not change with the plant extract supplementation compared with the control, and this result is consistent with the absence of effect on rumen $\mathrm{pH}$ (Hristov et al., 2013). On the other hand, when plant extracts were fed together in MIX, we noticed a decrease in the molar proportion of acetate and a tendency to increase the molar proportion of butyrate when compared with feeding both plant extracts separately. We also noticed a tendency to decrease the acetate-to-propionate ratio compared with feeding oregano extract. Other in vitro studies showed results varying from no effects to decrease in total VFA and increase in propionate and butyrate (Cobellis et al., 2016). In other study, condensed tannins present in GT reduced protozoa population and decreased VFA production and acetate-to-propionate ratio (Aemiro et al., 2016). Our results are partially not in accordance with the literature, as some in vivo studies reported reductions in propionate concentration and increase in acetate-topropionate ratio observed with green tea (Eruden et al., 2005) and in vitro studies reported an increase in C2 to C3 with oregano (Tekeli et al., 2015). However, in the current research, the results are in agreement with other studies that did not report significant changes in VFA concentrations and proportions (Nishina et al., 2006; Tekippe et al., 2011; Hristov et al., 2013) or a small reduction in acetate-to-propionate ratio (Aemiro et al., 2016).
The treatments used did not affect milk yield. Decreased methane emission expressed in dDMI might have increased rumen hydrogen availability, but if not converted into VFA, it would represent an energy loss as pointed out by Tekippe et al. (2011). Our results are in agreement with several studies with oregano (Hristov et al., 2013) but not with Eruden et al. (2005) who reported reduced milk production with the addition of $15 \%$ of green tea grounds silage in TMR. Body weight and BCS were unaffected by treatments. Overall productive performance was similar between treatments probably because intakes of DM, CP, NDF, and TDN did not significantly vary.

The first 2 hypotheses of the study, that extract of oregano and green tea reduce the emission of methane without harming productive performance, were confirmed. Plant extract compounds have a variety of different chemical structures, with specific properties and therapeutic functions (Burt, 2004). By the association of oregano and green tea extracts (MIX treatment) we sought to improve the previously demonstrated benefits of these extracts, because isolated compounds have sometimes been reported to have synergistic or additive effects when mixed (Benkeblia, 2004; Burt, 2004).

Palatability problems were not apparent in GT and OR treatments, but may be a possible issue when testing greater dosages. Further research could test the effects of plant extract associations as encapsulated products, preventing this negative effect on animal intake, which might lead to different responses in terms of digestibility, VFA concentrations, and gas production (Calsamiglia et al., 2007).

The third hypothesis, that oregano and green tea extract fed in association will present additive effects in reducing methane metrics, was not confirmed, as the MIX treatment did not increase the benefits of OR and GT administered separately. Small additive effects were detected for reduced digestibility of DM, CP, and GE and changes in the molar proportions of acetate and butyrate besides an increase in saturated short-chain fatty acids in milk.

Most of milk components were not altered by oregano and green tea extract, except for the negative effect of adding oregano in the fat content and a trend to reduce fat-to-protein ratio compared with the control. Because of the antimicrobial and antifungal activities of the plant extracts, it was thought that the changes that may be promoted in rumen microbial communities would lead to changes in the milk composition and milk fatty acid profile, and this was partially confirmed by our findings. The decrease in milk fat percentage and fat-to-protein ratio found when oregano was added in TMR compared with the control might be related to 
the decrease in the concentration of several short-chain SFA (Table 7), but is contradictory to our results for rumen VFA (Table 4). However, other studies reported an increase in acetate or in the acetate-to-propionate ratio (Tekippe et al., 2011) or did not find significant changes in the milk fatty acid profile (Benchaar and Chouinard, 2009; Hristov et al., 2013).

\section{CONCLUSIONS}

In conclusion, green tea and oregano did not influence variables such as DMI and milk production by dairy cows between 28 and $87 \mathrm{~d}$ of lactation. Animal performance variables were not affected by the use of these additives. Oregano and green tea were able to reduce $\mathrm{CH}_{4}$ emissions per kilogram of digestible DM ingested, which suggests that further studies on these feed additives may be warranted. With regard to totaltract apparent digestibility, MIX might be effective for the crossbred Holstein-Gir herds. We postulated that greater dosages, supplied as capsules, may demonstrate positive effects on animal production. Importantly, in this study, we observe some additive effect of the association of green tea and oregano on total-tract apparent digestibility, molar proportions of ruminal acetate and butyrate, and fatty acid profile in milk, but the same was not noticed on milk production or methane emissions.

\section{ACKNOWLEDGMENTS}

The authors thank to the Brazilian National Research Council, CNPq 473562/2012-0 for the research and fellow research grants, to the Brazilian Agricultural Research Corporation, EMBRAPA Dairy Cattle for providing the animals, structure, and employees for the experiment, to the FAPEMIG, CAPES, PECUS RumenGases Research Project, to Ivan dos Santos for the supply of the oregano extract, and to Marcelo T. Stumpf (Agroecology School, Federal University of Rio Grande, São Lourenço do Sul, Brazil) and Concepta McManus (Institute of Biological Sciences, University of Brasília, Brasília, Brazil) for reviewing this manuscript.

\section{REFERENCES}

Aemiro, A., M. Hanada, K. Umetusu, and T. Nishida. 2016. The effect of sunphenon 30S-0 on methane emission, nutrient intake, digestibility and rumen fermentation. Anim. Feed Sci. Technol. 214:34-43. https://doi.org/10.1016/j.anifeedsci.2016.02.007.

AOAC International. 2011. Official Methods of Analysis. 18th ed. AOAC International, Arlington, VA.

Baldin, M., M. A. S. Gama, R. Dresch, K. J. Harvatine, and D. E. Oliveira. 2013. A rumen unprotected conjugated linoleic acid supplement inhibits milk fat synthesis and improves energy balance in lactating goats. J. Anim. Sci. 91:3305-3314. https://doi.org/10 $.2527 /$ jas.2012-5766.

Becker, P. M., P. G. Van Wikselaar, M. C. R. Franssen, R. C. H. Vos, R. D. Hall, and J. Beekwilder. 2013. Evidence for a hydrogensink mechanism of $(+)$ catechin-mediated emission reduction of the ruminant greenhouse gas methane. Metabolomics 10:179-189. https://doi.org/10.1007/s11306-013-0554-5.

Benchaar, C., S. Calsamiglia, A. V. Chaves, G. R. Fraser, D. Colombatto, T. A. McAllister, and K. A. Beauchemin. 2008. A review of plant-derived essential oils in ruminant nutrition and production. Anim. Feed Sci. Technol. 145:209-228. https://doi.org/10.1016/j .anifeedsci.2007.04.014.

Benchaar, C., and P. Y. Chouinard. 2009. Short communication: Assessment of the potential of cinnamaldehyde, condensed tannins, and saponins to modify milk fatty acid composition of dairy cows. J. Dairy Sci. 92:3392-3396. https://doi.org/10.3168/jds.2009-2111.

Benkeblia, N. 2004. Antimicrobial activity of essential oil extracts of various onions (Allium cepa) and garlic (Allium sativum). Lebensm. Wiss. Technol. 37:263-268. https://doi.org/10.1016/j.lwt 2003.09.001.

Brouwer, E. 1965. Report of sub-committee on constants and factors. Pages 442-443 in Symposium of Energy Metabolism held at European Association for Animal Production. EAAP Academic, London, UK.

Burt, S. 2004. Essential oils: Their antibacterial properties and potential applications in foods-A review. Int. J. Food Microbiol. 94:223-253. https://doi.org/10.1016/j.ijfoodmicro.2004.03.022.

Calsamiglia, S., M. Busquet, P. W. Cardozo, L. Castillejos, and A. Ferret. 2007. Invited review: Essential oils as modifiers of rumen microbial fermentation. J. Dairy Sci. 90:2580-2595. https://doi .org/10.3168/jds.2006-644.

Cobellis, G., M. Trabalza-Marinucci, and Z. You. 2016. Critical evaluation of essential oils as rumen modifiers in ruminant nutrition: A review. Sci. Total Environ. 545-546:556-568. https://doi.org/10 .1016/j.scitotenv.2015.12.103.

Crespy, V., and G. Williamson. 2004. A review of the health effects of green tea catechins in in vivo animal models. J. Nutr. 134:3431S3440 S.

Cruz-Hernandez, C., J. K. G. Kramer, J. J. Kennelly, D. R. Glimm, B. M. Sorensen, E. K. Okine, L. A. Goonewardene, and R. J. Weselake. 2007. Evaluating the conjugated linoleic acid and trans 18:1 isomers in milk fat of dairy cows fed increasing amounts of sunflower oil and a constant level of fish oil. J. Dairy Sci. 90:37863801. https://doi.org/10.3168/jds.2006-698.

Detmann, E. M. A. Souza, S. C. Valadares Filho, A. C. Queiroz, T. T. Berchielli, E. O. S. Saliba, L. S. Cabral, D. S. Pina, M. M. Ladeira, and J. A. G. Azevêdo. 2012. Métodos para Análise de Alimentos. 1st ed. Suprema, Visconde do Rio Branco, MG, Brazil.

Eruden, B., T. Nishida, H. Matsuyama, K. Hosoda, and S. Shioya. 2005. Effect of the addition of various levels of green tea grounds silage at on the feed intake and milk production in lactating dairy cows. Anim. Sci. J. 76:295-301. https://doi.org/10.2508/chikusan .76 .295 .

Fonseca, L. F. L., and M. V. Santos. 2000. Qualidade do Leite e Controle da Mastite. Lemos Editorial, São Paulo, Brazil.

Heleno, S. A., A. Martins, M. J. R. Queiroz, and I. C. Ferreira. 2015. Bioactivity of phenolic acids: Metabolites versus parent compounds: A review. Food Chem. 173:501-513. https://doi.org/10 .1016/j.foodchem.2014.10.057.

Hristov, A. N., C. Lee, T. Cassidy, K. Heyler, J. A. Tekippe, G. A. Varga, B. Corl, and R. C. Brandt. 2013. Effect of Origanum vulgare L. leaves on rumen fermentation, production, and milk fatty acid composition in lactating dairy cows. J. Dairy Sci. 96:1189-1202. https://doi.org/10.3168/jds.2012-5975.

Hristov, A. N., C. Lee, T. Cassidy, M. Long, B. Corl, and R. Forster. 2011. Effects of lauric and myristic acids on ruminal fermentation, production, and milk fatty acid composition in lactating dairy cows. J. Dairy Sci. 94:382-395. https://doi.org/10.3168/jds.2010 -3508 .

IPCC. 2014. Climate Change 2014: Synthesis Report. Contribution of Working Groups I, II and III to the Fifth Assessment Report of the 
Intergovernmental Panel on Climate Change. Core Writing Team, R. K. Pachauri and L. A. Meyer, ed. IPCC, Geneva, Switzerland.

Johnson, K. A., and D. E. Johnson. 1995. Methane emissions from cattle. J. Anim. Sci. 73:2483-2492. https://doi.org/10.2527/1995 $.7382483 x$

Knapp, J. R., G. H. Laur, P. A. Vadas, W. P. Weiss, and J. M. Tricarico. 2014. Invited review: Enteric methane in dairy cattle production: Quantifying the opportunities and impact of reducing emissions. J. Dairy Sci. 97:3231-3261. https://doi.org/10.3168/jds .2013-7234

Lacerda, E. C. Q., L. C. Bauer, J. S. Oliveira, F. F. Silva, S. A. Carvalho, M. S. Macedo, N. E. Souza, and J. I. Simionato. 2014. Effect of the dietary inclusion of dried oregano (Origanum vulgare L.) on the characteristics of milk from Holstein x Zebu cows. Anim. Feed Sci. Technol. 192:101-105. https://doi.org/10.1016/j.anifeedsci 2014.03.007

Lauzon, K., X. Zhao, A. Bouetard, L. Delbecchi, B. Paquette, and P. Lacasse. 2005. Antioxidants to prevent bovine neutrophil-induced mammary epithelial cell damage. J. Dairy Sci. 88:4295-4303. https://doi.org/10.3168/jds.S0022-0302(05)73115-5.

Leiber, F., C. Kunz, and M. Kreuzer. 2012. Influence of different morphological parts of buckwheat (Fagopyrum esculentum) and its major secondary metabolite rutin on rumen fermentation in vitro. Czech J. Anim. Sci. 57:10-18.

Lejonklev, J., U. Kidmose, S. Jensen, M. A. Petersen, A. L. F. Helwing, G. Mortensen, M. R. Weisbjerg, and M. K. Larsen. 2016. Short communication: Effect of oregano and caraway essential oils on the production and flavor of cow milk. J. Dairy Sci. 99:7898-7903. https://doi.org/10.3168/jds.2016-10910.

Lejonklev, J., M. M. Lokke, M. K. Larsen, G. Mortensen, M. A. Petersen, and M. R. Weisbjerg. 2013. Transfer of terpenes from essential oils into cow milk. J. Dairy Sci. 96:4235-4241. https://doi .org/10.3168/jds.2012-6502.

Lighton, J. R. B. 2008. Measuring Metabolic Rates: A Manual for Scientists. Oxford University Press, Oxford, UK. https://doi.org/ 10.1093/acprof:oso/9780195310610.001.0001.

Lin, B., Y. Lu, A. Z. M. Salem, J. H. Wang, Q. Liang, and J. X. Liu. 2013. Effects of essential oil combinations on sheep ruminal fermentation and digestibility of a diet with fumarate included. Anim. Feed Sci. Technol. 184:24-32. https://doi.org/10.1016/j anifeedsci.2013.05.011.

Machado, F. S., T. R. Tomich, A. L. Ferreira, L. F. L. Cavalcanti, M. M. Campos, C. A. V. Paiva, M. N. Ribas, and L. G. P. Pereira. 2016. A facility for respiration measurements in cattle. J. Dairy Sci. 99:4899-4906. https://doi.org/10.3168/jds.2015-10298.

NRC. 2001. Nutrient Requirements of Dairy Cattle. 7th rev. ed. Natl. Acad. Press, Washington, DC. https://doi.org/10.17226/9825.

Nishida, T., B. Eruden, K. Hosada, H. Matsuyama, K. Nakagawa, T. Miyazawa, and S. Shioya. 2006. Effects of green tea (Camellia sinensis) waste silage and polyethylene glycol on ruminal fermentation and blood components in cattle. Asian-australas. J. Anim. Sci. 19:1728-1736. https://doi.org/10.5713/ajas.2006.1728.

Oh, J., and A. N. Hristov. 2016. Effects of plant-derived bio-active compounds on rumen fermentation, nutrient utilization, immune response, and productivity of ruminant animals. Pages 167-186 in Medicinal and Aromatic Crops: Production, Phytochemistry, and Utilization. V. D. Jeliazkov (Zheljazkov) and C. L. Cantrell, ed. American Chemical Society Publications, Washington, DC https://doi.org/10.1021/bk-2016-1218.ch011.

Oh, J., E. H. Wall, D. M. Bravo, and A. N. Hristov. 2017. Host-mediated effects of phytonutrients in ruminants: A review. J. Dairy Sci. 100:5974-5983. https://doi.org/10.3168/jds.2016-12341.

Ohene-Adjei, S., A. V. Chaves, T. A. McAllister, C. Benchaar, R. M. Teather, and R. J. Forster. 2008. Evidence of increased diversity of methanogenic archaea with plant extract supplementation. Microb. Ecol. 56:234-242. https://doi.org/10.1007/s00248-007-9340 -0 .

Patra, A. K. 2012. Enteric methane mitigation technologies for ruminant livestock: A synthesis of current research and future directions. Environ. Monit. Assess. 184:1929-1952. https://doi.org/10 $.1007 / \mathrm{s} 10661-011-2090-\mathrm{y}$.

Robertson, J. B., and P. J. Van Soest. 1981. The detergent system of analysis and its application to human foods. Pages 123-158 in The Analysis of Dietary Fiber in Food. W. P. T. James and O. Theander, ed. Marcel Dekker Inc., New York, NY.

Roy, D., S. K. Tomar, S. K. Sirohi, V. Kumar, and M. Kumar. 2014. Efficacy of different essential oils in modulating rumen fermentation in vitro using buffalo rumen liquor. Vet. World 7:213-218. https://doi.org/10.14202/vetworld.2014.213-218 .

Siegfried, B. R., H. Ruckemann, and G. Stumpf. 1984. Method for the determination of organic acids in silage by high performance liquid chromatography. Landwirtsch. Forsch. 37:298-304.

Szumacher-Strabel, M., and A. Cieślak. 2012. Dietary possibilities to mitigate rumen methane and ammonia production in Greenhouse gases capturing, utilization and reduction. Ed. Gouxiang Leu. Intech, Open Access Publisher, Croatia. https://doi.org/10.5772/ 32105 .

Tekeli, A., G. Yıldız, W. Drochner, and H. Steingass. 2015. Efficacy of essence oil supplementation to feeds on volatile fatty acid production. Rev. Mvz Cordoba 20(Suppl. 1):4884-4894. https://doi.org/ $10.21897 / \mathrm{rmvz} .4$

Tekippe, J. A., A. N. Hristov, K. S. Heyler, T. W. Cassidy, V. D. Zheljazkov, J. F. S. Ferreira, S. K. Karnati, and G. A. Varga. 2011. Rumen fermentation and production effects of Organum vulgare leaves in lactating cows. J. Dairy Sci. 94:5065-5079. https://doi .org/10.3168/jds.2010-4095.

Tronco, V. M. 2013. Manual para Inspeção da Qualidade do Leite. 5th ed. Editora UFSM, Santa Maria, Brazil.

Valente, T. N. P., E. Detmann, A. C. de Queiroz, S. C. Valadares Filho, D. I. Gomes, and J. F. Figueiras. 2011. Evaluation of ruminal degradation profiles of forages using bags made from different textiles. Rev. Bras. Zootec. 40:2565-2573. https://doi.org/10 .1590/S1516-35982011001100039.

Van Soest, P. J., and J. B. Robertson. 1985. Analysis of Forages and Fibrous Foods. Cornell University Press, Ithaca, NY.

Van Soest, P. J., J. B. Robertson, and B. A. Lewis. 1991. Methods for dietary fiber, neutral detergent fiber, and non-starch polysaccharides in relation to animal nutrition. J. Dairy Sci. 74:3583-3597. https://doi.org/10.3168/jds.S0022-0302(91)78551-2.

Wallace, R. J., N. R. McEwan, F. M. McIntosh, B. Teferedegne, and C. J. Newbold. 2002. Natural products as manipulators of rumen fermentation. Asian-australas. J. Anim. 15:1458-1468. https://doi .org/10.5713/ajas.2002.1458.

Wildman, E., G. M. Jones, and P. E. Wagner. 1982. A dairy cow body condition scoring system and its relationship to selected production characteristics. J. Dairy Sci. 65:495-501. https://doi.org/10 .3168/jds.S0022-0302(82)82223-6.

Winkler, A., D. K. Gessner, C. Koch, F. J. Romberg, G. Dusel, E. Herzog, E. Most, and K. Eder. 2015. Effects of a plant product consisting of green tea and curcuma extract on milk production and the expression of hepatic genes involved in endoplasmic stress response and inflammation in dairy cows. Arch. Anim. Nutr. 69:425-441. https://doi.org/10.1080/1745039X.2015.1093873.

Wolff, R. L., C. C. Bayard, and R. J. Fabien. 1995. Evaluation of sequential methods for the determination of butterfat fatty acid composition with emphasis on trans-18:1 acids. Application to the study of seasonal variations in French butters. J. Am. Oil Chem. Soc. 72:1471-1483. https://doi.org/10.1007/BF02577840. 